\title{
Cuticular Phenolics and Scald Development in 'Delicious' Apples
}

\author{
Zhiguo Ju' ${ }^{1}$ and William J. Bramlage \\ Department of Plant and Soil Sciences, University of Massachusetts, Amherst, MA 01003
}

\begin{abstract}
ADDITIONAL INDEX wORDS. antioxidants, ethylene, $\alpha$-farnesene, fruit cuticle, Malus sylvestris var. domestica.
Abstract. Influences of fruit maturity, AVG and ethephon preharvest treatments, and storage conditions on cuticular phenolic concentration, $\alpha$-farnesene accumulation and oxidation, and scald development of 'Delicious' apples [Malus sylvestris (L.) Mill. var.domestica (Borkh.) Mansf.] were studied. Advanced maturity and ethephon treatment increased free phenolics in fruit cuticle at harvest, while AVG treatment caused a reduction. Free cuticular phenolics increased during early storage in ethephon-treated and nontreated fruit but not in AVG-treated apples. Advanced maturity and ethephon did not alter $\alpha$-farnesene accumulation overall, but reduced conjugated triene (CT281) formation and scald development. When stored in a low-ethylene room $\left(<1 \mu \mathrm{L} \cdot \mathrm{L}^{-1}\right)$, AVG-treated fruit accumulated very low levels of $\alpha$-farnesene and CT281 and did not develop scald after 6 months at $0^{\circ} \mathrm{C}$. When stored in a commercial room (ambient ethylene $>5 \mu \mathrm{L} \cdot \mathrm{L}^{-1}$ ), the AVG-treated and control fruit accumulated similar amounts of $\alpha$-farnesene and CT281 and developed similar percentages of scald. In general, free phenolic concentrations in fruit cuticle were negatively correlated with CT281 formation and scald development of apples. Chemical names used: aminoethoxyvinylglycine (AVG); 2-chloroethylphosphonic acid (ethephon).
\end{abstract}

Scald development in apples (Malus sylvestris var. domestica) involves $\alpha$-farnesene accumulation and oxidation (Anet, 1969; Huelin and Murray, 1966; Ingle and D'Souza, 1989, Whitaker et al., 1997). The antioxidant diphenylamine (DPA) inhibits $\alpha$-farnesene oxidation and reduces scald (Anet and Coggiola, 1974; Huelin and Coggiola, 1970; Meigh and Filmer, 1969), which leads to the hypothesis that antioxidants can play critical roles in reducing scald in apples (Anet, 1974; Barden and Bramlage, 1994a, 1994b; Gallerani et al., 1990; Meir and Bramlage, 1988). Since accumulation of $\alpha$-farnesene occurs primarily in the fruit cuticle (Huelin and Murray, 1966; Murray et al., 1964; Wee and Beaudry, 1997), the presence of antioxidants within fruit cuticles could be an effective defense against $\alpha$-farnesene oxidation. In a recent study, Ju and Bramlage (1999) detected both lipid-soluble and hydrophilic antioxidants in the fruit cuticle, with the lipid-soluble antioxidants accounting for only $\approx 10 \%$ to $15 \%$ (on a molar basis) of the total activity of lipidsoluble antioxidants in the fruit peel. This concentration neither inhibits linoleic acid oxidation in a linoleic acid (oil-in-water) system, nor protects $\alpha$-farnesene from oxidation in a hexane solution (bulk oil). The hydrophilic antioxidants (phenolics), however, display antioxidant activity similar to that of DPA in a linoleic acid system and higher activity than DPA in an $\alpha$ farnesene-hexane solution. The fruit cuticle is likely a water-inoil emulsion rather than a totally lipophilic domain, as it is composed of lipophilic (wax), hydrophilic (pectin and polycarbohydrates), and emulsifying (fatty acids or ursolic acid) substances (Holloway, 1992). In this environment, hydrophilic antioxidants like phenolics might be more important than the lipophilic antioxidants in inhibiting $\alpha$-farnesene oxidation. However, the relationships between cuticular phenolics and $\alpha$ -

Received for publication 23 Oct. 1998. Accepted for publication 3 Jan. 2000 Massachusetts Agricultural Experiment Station paper No. 3228. This research was supported in part by Experiment Station Project No. 517. We are grateful to Bernard Rubinstein, Thomas L. Potter, and Kalidas Shetty of the University of Massachusetts for kindly providing some of the materials and instruments used in this study. The cost of publishing this paper was defrayed in part by the payment of page charges. Under postal regulations, this paper therefore must be hereby marked advertisement solely to indicate this fact.

${ }^{1}$ Current address: USDA-ARS, Tree Fruit Research Laboratory, 1104 North Western Ave., Wenatchee, WA 98801. farnesene oxidation or scald development have not been studied.

Although $\alpha$-farnesene accumulation corresponds closely with ethylene $\left(\mathrm{C}_{2} \mathrm{H}_{4}\right)$ production in apples (Barden and Bramlage, 1994a, 1994b; Du and Bramlage, 1994; Meigh and Filmer, 1969; Watkins et al., 1993), the role of $\mathrm{C}_{2} \mathrm{H}_{4}$ in $\alpha$-farnesene accumulation and scald development is unclear. Since the above results were correlative and represented only an increase of $\alpha$-farnesene with increasing $\mathrm{C}_{2} \mathrm{H}_{4}$ levels, we do not know whether $\alpha$-farnesene accumulation is regulated directly by $\mathrm{C}_{2} \mathrm{H}_{4}$ or is just coincidental with its increase. In addition, although $\alpha$-farnesene accumulation and oxidation are associated closely with scald development (Ingle and D'Souza, 1989; Whitaker, 1997), application of ethephon often induces an early increase in $\alpha$-farnesene as well as scald reduction (Barden and Bramlage, 1994a, 1994b; Curry, 1994; Du and Bramlage, 1994; Lurie et al., 1989; Watkins et al., 1993). Scrubbing $\mathrm{C}_{2} \mathrm{H}_{4}$ from the storage room can be either effective (Dover, 1985; Knee and Hatfield, 1981; Shorter et al., 1992) or ineffective (Chellew and Little, 1995; Lau, 1998) in reducing scald. Since $\mathrm{C}_{2} \mathrm{H}_{4}$ scrubbing does not inhibit $\mathrm{C}_{2} \mathrm{H}_{4}$ biosynthesis, ambient $\mathrm{C}_{2} \mathrm{H}_{4}$ levels may remain higher than the physiologically active concentration of $\mathrm{C}_{2} \mathrm{H}_{4}$ (Chellew and Little, 1995; Lau, 1998), and even when external $\mathrm{C}_{2} \mathrm{H}_{4}$ is low, internal $\mathrm{C}_{2} \mathrm{H}_{4}$ might be high enough to cause physiological changes. To resolve these inconsistent or unclear results, $\mathrm{C}_{2} \mathrm{H}_{4}$ levels in fruit need to be manipulated. AVG is an inhibitor of 1-amino-cyclopropane-1-carboxylic acid synthase and has been used widely to inhibit $\mathrm{C}_{2} \mathrm{H}_{4}$ biosynthesis in apples (Autio and Bramlage, 1982; Bangerth, 1978; Bramlage et al., 1980), providing a tool to explore the role of $\mathrm{C}_{2} \mathrm{H}_{4}$ in regulating $\alpha$-farnesene accumulation and affecting scald in apples.

The objectives of this study were to 1) modify scald development by harvesting fruit at different maturity, manipulating fruit $\mathrm{C}_{2} \mathrm{H}_{4}$ biosynthesis, and using storage rooms with different ambient $\mathrm{C}_{2} \mathrm{H}_{4}$ concentrations, 2) investigate the possible role of $\mathrm{C}_{2} \mathrm{H}_{4}$ in regulating phenolic and $\alpha$-farnesene accumulations in fruit cuticles, and 3) examine the relationship between cuticular phenolic concentration and $\alpha$-farnesene oxidation, or between cuticular phenolic concentration and scald development in 'Delicious' apples. Our hypothesis was that cuticular phenolics may play a key role in regulating scald development due to their ability to inhibit oxidation of $\alpha$-farnesene. 


\section{Materials and Methods}

\section{Plant materials and treatments}

The following experiments were conducted at the Horticultural Research Center of the University of Massachusetts, Belchertown, Mass.

Avg AND EThePhon. In 1993, a block of mature 'Delicious' trees on Malling 26 (M.26) rootstocks growing under commercial horticultural management was selected and five, one- or two-tree plots (depending on fruit load) were sprayed 9 Sept. with AVG (Abbott Labs, Chicago, Ill.) at $1.0 \mathrm{mmol} \cdot \mathrm{L}^{-1}\left(200 \mathrm{mg} \cdot \mathrm{L}^{-1}\right)$ plus a surfactant (Regulaid, Kalo, Inc., Overland Park, Kan.) at $0.1 \%$ (v/ v) to runoff with a hand sprayer. Five nonsprayed plots served as controls. The 10 plots were arranged in a completely randomized design. About 160 fruit per plot were harvested on 5 Oct., with 10 being used to evaluate fruit maturity, another 10 to measure internal $\mathrm{C}_{2} \mathrm{H}_{4}, \alpha$-farnesene, and conjugated trienes (CT281), and the remaining fruit being placed in kraft paper bags and stored in a commercial room in air at $0{ }^{\circ} \mathrm{C}$. At the same time, 50 fruit per AVG-treated plot were harvested and placed in a low- $\mathrm{C}_{2} \mathrm{H}_{4}, 0^{\circ} \mathrm{C}$, room (only AVG-treated fruit were present). At 5, 10, 15, 20, and 25 weeks, 10 fruit per sample from the commercial room were removed for $\mathrm{C}_{2} \mathrm{H}_{4}, \alpha$-farnesene, and CT281 measurement. From the low- $\mathrm{C}_{2} \mathrm{H}_{4}$ room, a composite 10-fruit sample was taken for these measurements. Air samples from the low $-\mathrm{C}_{2} \mathrm{H}_{4}$ room were taken regularly to detect ambient $\mathrm{C}_{2} \mathrm{H}_{4}$ levels. After 25 weeks of storage, the remaining fruit were evaluated for scald (see below) after $7 \mathrm{~d}$ at $20^{\circ} \mathrm{C}$.

In 1995,18 one- or two-tree plots were divided randomly among three treatments: AVG at $1.1 \mathrm{mmol} \cdot \mathrm{L}^{-1}$ applied $12 \mathrm{Sept}$; ethephon at $1.4 \mathrm{mmol} \cdot \mathrm{L}^{-1}\left(200 \mathrm{mg} \cdot \mathrm{L}^{-1}\right)$ (Rhone-Poulenc, AG, N.C.) applied 19 Sept.; and a control. Three hundred fruit from each ethephon-treated and control plot, and 600 fruit from each AVG-treated plot were harvested 28 Sept. Half of the AVGtreated fruit were stored in a low- $\mathrm{C}_{2} \mathrm{H}_{4}$ room (as in 1993) at $0{ }^{\circ} \mathrm{C}$, while the other half were maintained in a commercial air storage with the ethephon-treated and control fruit at $0{ }^{\circ} \mathrm{C}$.

At harvest, 12 fruit per plot were used for maturity evaluation, with the peels (removed with a mechanical peeler) being used for phenolic measurements. Another 12 fruit were used for internal $\mathrm{C}_{2} \mathrm{H}_{4}, \alpha$-farnesene, and CT281 measurements. At 1 to 6 months of storage, 12 fruit per sample were taken for measuring $\mathrm{C}_{2} \mathrm{H}_{4}, \alpha$ farnesene, and CT281. At 3 and 6 months of storage, another 12 fruit were used for cuticular phenolic measurements. Ambient $\mathrm{C}_{2} \mathrm{H}_{4}$ in both the commercial and low $-\mathrm{C}_{2} \mathrm{H}_{4}$ rooms was monitored every month. Scald was evaluated after 5 and 6 months of storage following $7 \mathrm{~d}$ at $20^{\circ} \mathrm{C}$.

Fruit Maturity. In 1994, four, two-tree plots (replicates) in a block of mature 'Delicious' trees were selected for a maturity and scald susceptibility study. From each plot, 230 fruit were harvested 28 Sept. and 19 Oct., respectively. Ten of the fruit were used for maturity evaluation, 10 for internal $\mathrm{C}_{2} \mathrm{H}_{4}, \alpha$-farnesene, and CT281 measurement, and another 10 for cuticular phenolic analysis. The rest of the fruit were maintained in air storage at 0 ${ }^{\circ} \mathrm{C}$. Internal $\mathrm{C}_{2} \mathrm{H}_{4}, \alpha$-farnesene, CT281, and cuticular phenolics were measured after 15 and 25 weeks of storage. Scald was evaluated after 25 weeks at $0{ }^{\circ} \mathrm{C}$ plus $7 \mathrm{~d}$ at $20^{\circ} \mathrm{C}$.

In 1996, fruit were harvested 7 Sept. (early harvest), 28 Sept. (middle harvest), and 19 Oct. (late harvest). Samples were assayed at 0,15 , and 22 weeks of storage, and scald was evaluated after 22 weeks of $0{ }^{\circ} \mathrm{C}$ air storage plus $7 \mathrm{~d}$ at $20^{\circ} \mathrm{C}$.

\section{Fruit maturity and scald evaluation}

The green area of the fruit peel was estimated visually as the percentage of total fruit area. Flesh firmness was measured on two sides of each fruit with a UC Firmness Tester (Western Industrial Supply, Inc., Davis, Calif.) after the peel was removed. Starch was evaluated by dipping one half of each fruit, cut at the equator, in an iodine-potassium iodide solution for approximately $30 \mathrm{~s}$. The degree of staining was rated on a scale of 1 to 9 where $1=$ staining of the entire cut surface and $9=$ absence of staining (Priest and Lougheed, 1988).

At least 100 fruit were used in all scald evaluations. Scald was recorded both as percentage incidence and as intensity, using the scale of $0=$ none, $1=1 \%$ to $10 \%, 2=11 \%$ to $33 \%, 3=34 \%$ to $66 \%$, and $4=67 \%$ to $100 \%$ of the surface area affected. Intensity was calculated as mean score of the fruit with a score of 1 or higher.

\section{Measurement of ethylene, $\alpha$-farnesene, and conjugated trienes}

Ethylene was measured by gas chromatography with a $0.5 \mathrm{~mm}$ activated aluminum column and a flame-ionization detector (GC8A, Shimadzu, Tokyo, Japan). A sample of gas was taken from the core of each fruit using a 3 -mL syringe with $1 \mathrm{~mL}$ being injected into the column.

Extraction and measurement of $\alpha$-farnesene and conjugated trienes were conducted according to the procedure of $\mathrm{Du}$ and Bramlage (1993). Ten or 12 fruit were dipped individually in 150 $\mathrm{mL}$ of high pressure liquid chromatograph (HPLC)-grade hexane for 3 min each. Ultra violet absorbance of properly diluted hexane extracts was measured by spectroscopy (Model 200, Hitachi, Tokyo, Japan) at 232, 281, and $290 \mathrm{~nm}$. Concentrations of $\alpha$-farnesene and CT281 in hexane extracts were calculated from OD232 (El232 $=27,700$ ) and OD281 - OD290, respectively, according to Huelin and Coggiola (1968). Data are presented on the basis of fruit surface area, calculated from volume assuming that the fruit are spheres.

\section{Fruit cuticle separation and phenolic measurement}

Fruit cuticles were separated by enzymatic digestion and phenolics in the cuticle were isolated and measured as described previously (Ju and Bramlage, 1999). Frozen fruit peels were warmed to $20{ }^{\circ} \mathrm{C}$. Flesh on the peel was removed gently with a knife and the peels were washed with distilled water. Discs were then cut from the peels with a 0.8 -cm-diameter cork borer and incubated in 0.5 methanol (100\%) : 1 water : $0.01 \mathrm{HCl}(100 \%)$ (by volume) for $5 \mathrm{~min}$ to remove phenolics from cells under the cuticle. After washing with distilled water, the discs were incubated in an enzyme solution containing $2 \%(\mathrm{v} / \mathrm{v})$ pectinase $(365$ units $/ \mathrm{L}), 1 \%(\mathrm{w} / \mathrm{v})$ cellulase $(9.8$ units $/ \mathrm{mL}$ ), and $0.05 \%$ (v/v) pectin lyase (125 units/L) (Sigma, St. Louis, Mo.) in acetate buffer at $\mathrm{pH} 4$. After incubation at $35^{\circ} \mathrm{C}$ for $48 \mathrm{~h}$ with constant shaking, the discs were removed and brushed carefully to remove adhering epidermal remnants. The liberated cuticles were incubated a second time at $35^{\circ} \mathrm{C}$ in a new enzyme solution (with the same enzyme concentration) for another $24 \mathrm{~h}$ and any remaining epidermal remnants were removed by brushing. Samples were examined under a microscope to ensure there were no epidermal cells attached to the cuticular membrane. Cuticular membranes were washed with distilled water and then with 0.27 $\mathrm{mol} \cdot \mathrm{L}^{-1}(1 \%, \mathrm{v} / \mathrm{v}) \mathrm{HCl}$ solution, dried at $35^{\circ} \mathrm{C}$ for $24 \mathrm{~h}$, and stored at $-4{ }^{\circ} \mathrm{C}$.

Free phenolics in the fruit cuticle were extracted in two steps. First, the fruit cuticle was extracted twice with hexane for $10 \mathrm{~min}$. The residue then was extracted twice with methanol (containing 
Table 1. Effects of harvest dates and storage duration on internal ethylene, starch, $\alpha$-farnesene, and conjugated triene (CT281) accumulations, and scald development of 'Delicious' apples in 1996.

\begin{tabular}{|c|c|c|c|c|c|c|}
\hline $\begin{array}{l}\text { Harvest } \\
\text { date }\end{array}$ & $\begin{array}{c}\text { Weeks } \\
\text { in storage }\end{array}$ & $\begin{array}{l}\text { Ethylene } \\
\left(\mu \mathrm{L} \cdot \mathrm{L}^{-1}\right)\end{array}$ & $\begin{array}{l}\text { Starch } \\
\text { score }^{\mathrm{z}}\end{array}$ & $\begin{array}{l}\alpha \text {-Farnesene } \\
\left(\mathrm{nmol} \cdot \mathrm{cm}^{-2}\right)\end{array}$ & $\begin{array}{c}\text { CT281 } \\
\left(\mathrm{nmol} \cdot \mathrm{cm}^{-2}\right)\end{array}$ & $\begin{array}{c}\text { Scald } \\
(\%)\end{array}$ \\
\hline \multirow[t]{3}{*}{7 Sept. } & 0 & 0 & 1.0 & 0 & 0 & \\
\hline & 15 & 57 & & 147 & 8.8 & \\
\hline & 22 & 51 & & 97 & 13.0 & 87 \\
\hline \multirow[t]{3}{*}{28 Sept. } & 0 & 1 & 2.1 & 0 & 0 & \\
\hline & 15 & 72 & & 155 & 5.8 & \\
\hline & 22 & 53 & & 115 & 7.2 & 51 \\
\hline \multirow[t]{3}{*}{19 Oct. } & 0 & 37 & 5.1 & 3 & 0.7 & \\
\hline & 15 & 75 & & 152 & 6.0 & \\
\hline & 22 & 34 & & 97 & 4.8 & 28 \\
\hline Harvest & & $*$ & $* * * *$ & NS & $* * * *$ & $* * * *$ \\
\hline Linear & & $* *$ & $* * * *$ & NS & $* * * *$ & $* * * *$ \\
\hline Quadratic & & $*$ & NS & NS & NS & NS \\
\hline Storage & & $* * * *$ & & $* * * *$ & $* * * *$ & \\
\hline Linear & & $* *$ & & $* *$ & $* * * *$ & \\
\hline Quadratic & & $* * * *$ & & $* * * *$ & NS & \\
\hline Harvest $\times$ storage & & NS & & NS & $* * * *$ & \\
\hline
\end{tabular}

$\mathrm{z} 1$ to $3=$ immature; 4 to $6=$ mature; 7 to $9=$ overmature.

Ns, $* * *, * * * * *$ Nonsignificant or significant at $P \leq 0.05,0.01$, or 0.0001 , respectively.

$\mathrm{HCl}$ at $0.27 \mathrm{~mol} \cdot \mathrm{L}^{-1}$ ) to produce solution I. The hexane extracts were combined and then diluted with an equal volume of methanol $(100 \%)$-water- $\mathrm{HCl}(100 \%)(1: 1: 0.02$, by volume) in a separatory funnel to form a two-phase system, hexane and methanol-water. The hexane layer containing wax was washed twice with $\mathrm{HCl}$ at 0.27 $\mathrm{mol} \cdot \mathrm{L}^{-1}$ and discarded. The methanol-water layer and $\mathrm{HCl}$ wash at $0.27 \mathrm{~mol} \cdot \mathrm{L}^{-1}$ were combined to form solution II. Solutions I and II were combined and concentrated under reduced pressure. Free phenolics in the concentrate were purified on a silica gel column chromatograph equipped with a UV detector (Retriever II, Isco, Lincoln, Nebr.). The column was washed with hexane to remove wax contaminants and then with methanol to elute phenolics. Free phenolics were measured with the Folin-Ciocalteu method (Singleton and Rossi, 1965).

The residue from the above extraction was refluxed for $12 \mathrm{~h}$ in oxygen-free aqueous $\mathrm{KOH}$ at $0.53 \mathrm{~mol} \cdot \mathrm{L}^{-1}(3 \%, \mathrm{w} / \mathrm{v})$ to release the bound phenolics in the cuticle, which were recovered in ether after acidification with $\mathrm{HCl}$ at $2.74 \mathrm{~mol} \cdot \mathrm{L}^{-1}$ (Bakeret al., 1982; Huelin and Gallop, 1951) and measured with the Folin-Ciocalteu procedure (Singleton and Rossi, 1965).

\section{Statistical analysis}

Data were subjected to analysis of variance and regression, while pooled data were used for correlations, using SAS Statistical Software (SAS Institute, Inc., Cary, N.C.). In Tables 2 and 5, means were separated using Duncan's multiple range test at $P \leq 0.05$. In figures, means were compared by Tukey's studentized range test (HSD procedure) at $P \leq 0.05$. Unless noted otherwise, only results significant at $P \leq 0.05$ are discussed.

\section{Results}

Fruit maturation, $\alpha$-FARNESENE ACCUMULATION AND OXIDATION, AND SCALD DEVELOPMENT OF 'DELICIOUS' APPLES FROM DIFFERENT HARVEST DATES. Data from 1994 and 1996 followed the same trends, so only data from 1996 are presented in Table 1. At harvest, internal $\mathrm{C}_{2} \mathrm{H}_{4}$ and starch scores indicated that the early-harvest fruit were immature. The mid-harvest fruit were also immature accord- ing to the starch score but had begun the $\mathrm{C}_{2} \mathrm{H}_{4}$ climacteric rise, and the late-harvest fruit were mature with high levels of internal $\mathrm{C}_{2} \mathrm{H}_{4}$. Only the late-harvest fruit had detectable $\alpha$-farnesene at harvest.

Internal $\mathrm{C}_{2} \mathrm{H}_{4}, \alpha$-farnesene, and CT281 concentrations increased during cold storage compared with harvest values (Table 1). Internal $\mathrm{C}_{2} \mathrm{H}_{4}$ and $\alpha$-farnesene showed quadratic increases, while accumulation of CT281 increased linearly. There were no differences in $\alpha$ farnesene accumulation during the whole storage period among the three harvests, but delay of harvest reduced CT281 formation and scald incidence.

Interactions between harvest dates and storage durations were not significant for $\mathrm{C}_{2} \mathrm{H}_{4}$ and $\alpha$-farnesene accumulation but were significant for CT281 formation, in that the early harvested fruit accumulated the most while late harvested fruit accumulated the least CT281 by the end of storage.

FREE AND BOUND PHENOLICS IN CUTICLE OF FRUIT WITH DIFFERENT MATURITY. Free phenolics increased in the cuticle with advanced fruit maturity and linear regression was significant (Fig. 1A). Compared with early harvested fruit, free cuticular phenolics increased by about $80 \%$ in mid-harvest fruit, and by about $230 \%$ in late-harvest fruit. Advancing fruit maturation increased bound phenolic contents in the fruit cuticle by about $70 \%$ in mid-harvested fruit and $140 \%$ in late-harvested fruit (Fig. 1B). During cold storage, free phenolics in fruit cuticle of all treatments increased in early storage, and then remained constant (Fig. 1A), but there were no changes in bound phenolics in fruit cuticle of any treatment during storage (Fig. 1B).

EFFECTS OF ETHEPHON AND AVG ON FRUIT MATURITY AND $\mathrm{C}_{2} \mathrm{H}_{4}$ ACCUMULATION DURING COLD STORAGE. AVG treatment inhibited $\mathrm{C}_{2} \mathrm{H}_{4}$ synthesis at harvest to a very low level in both 1993 and 1995 (Table 2). Fruit firmness was higher and starch score was lower in AVG-treated fruit than those in controls in 1995, but not in 1993. Percentage green area of fruit peel was higher in AVG-treated fruit than that in controls in 1995. These differences indicated that fruit maturity was delayed following AVG treatment in 1995. Conversely, ethephon preharvest treatment increased internal $\mathrm{C}_{2} \mathrm{H}_{4}$ concentration and advanced fruit maturity at harvest.

When stored in a low- $\mathrm{C}_{2} \mathrm{H}_{4}$ room in 1993, AVG-treated fruit 


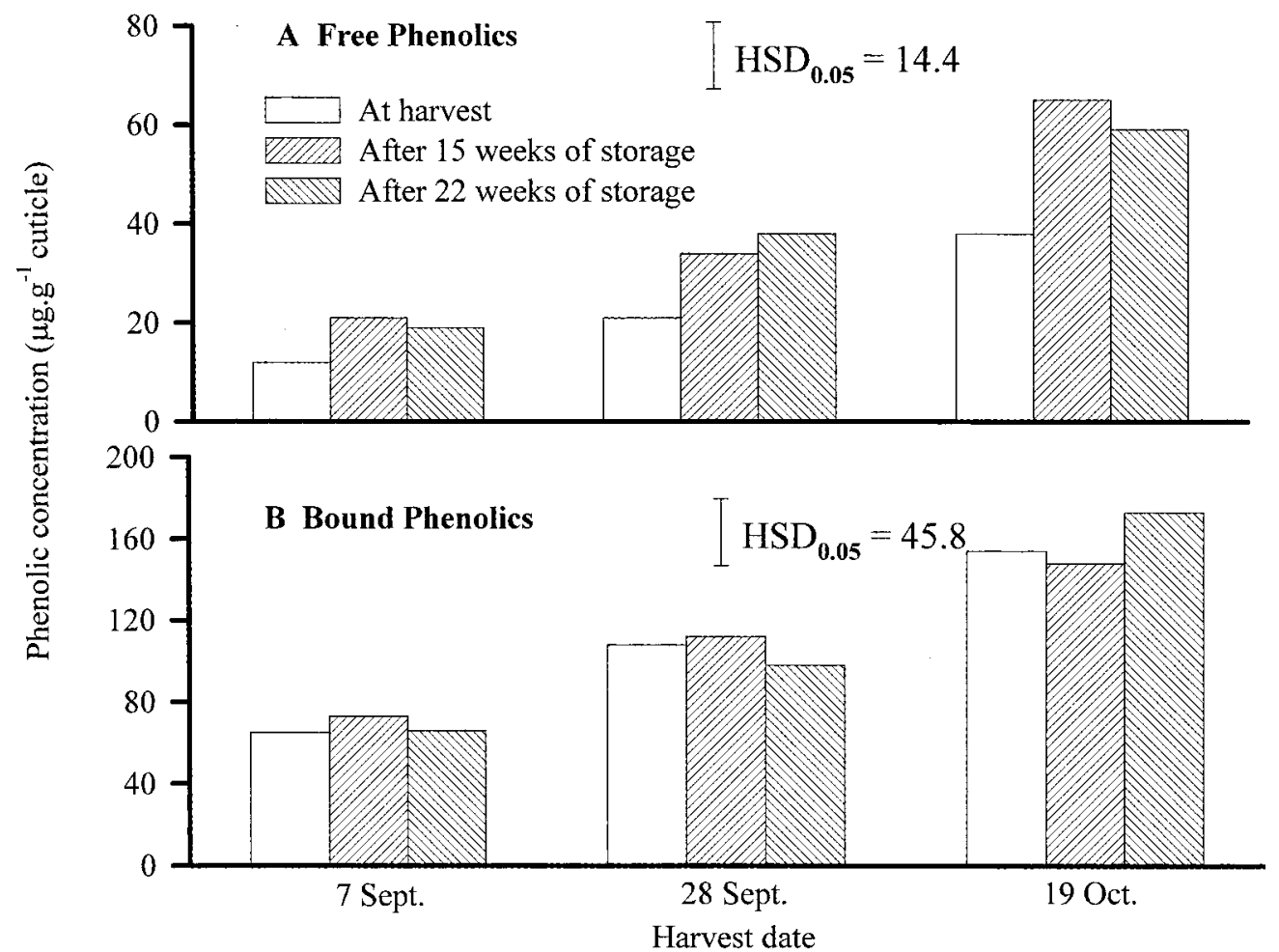

5 to $38 \mu \mathrm{L} \cdot \mathrm{L}^{-1}$ during storage, much higher than the internal $\mathrm{C}_{2} \mathrm{H}_{4}$ in AVGtreated fruit. Internal $\mathrm{C}_{2} \mathrm{H}_{4}$ in ethephon-treated fruit was higher than that in controls at harvest and during the first 3 months of storage, but was similar to that in the control fruit thereafter.

EFFECTS OF ETHEPHON AND AVG ON $\alpha$-FARNESENE AND CT281 ACCUMULAtion in Fruit cuticle. In the low$\mathrm{C}_{2} \mathrm{H}_{4}$ room, $\alpha$-farnesene in AVGtreated fruit in 1995 was barely detectable during 4 months at $0{ }^{\circ} \mathrm{C}$. Even after 6 months, $\alpha$-farnesene concentration was only $8 \mathrm{nmol} \cdot \mathrm{cm}^{-2}$ (Table 4). In contrast, $\alpha$-farnesene started to accumulate in AVG-treated fruit only after 5 weeks in 1993 (Table 3) with a final concentration of $51 \mathrm{nmol} \cdot \mathrm{cm}^{-2}$.

In the commercial room, internal $\mathrm{C}_{2} \mathrm{H}_{4}$ was lower in AVG-treated fruit than in control fruit in 1993, but there was no difference in $\alpha$-farnesene accumulation between them (Table 3 ). $\alpha$-Farnesene increased greatly within

Fig. 1. Effects of fruit maturity and storage duration on (A) free and (B) bound phenolics in fruit cuticle of 'Delicious' apples in 1996. The interaction between harvests and storage times was significant. $\mathrm{HSD}=$ honestly significant difference.

contained $<1 \mu \mathrm{L} \cdot \mathrm{L}^{-1}$ internal $\mathrm{C}_{2} \mathrm{H}_{4}$ through 10 weeks of storage (Table 3). Internal $\mathrm{C}_{2} \mathrm{H}_{4}$ increased thereafter and reached $8 \mu \mathrm{L} \cdot \mathrm{L}^{-1}$ at 25 weeks of storage. In 1995, AVG-treated fruit accumulated only $0.5 \mu \mathrm{L} \cdot \mathrm{L}^{-1} \mathrm{C}_{2} \mathrm{H}_{4}$ at 6 months of storage when the fruit were stored in the low- $\mathrm{C}_{2} \mathrm{H}_{4}$ room (Fig. 2). Ambient $\mathrm{C}_{2} \mathrm{H}_{4}$ levels both inside fruit packages (kraft paper bags) and in the storage room were below detectable limits in both years in the low- $\mathrm{C}_{2} \mathrm{H}_{4}$ room (data not presented).

In the commercial storage room in 1993 , internal $\mathrm{C}_{2} \mathrm{H}_{4}$ concentration in AVG-treated fruit increased from $0.2 \mu \mathrm{L} \cdot \mathrm{L}^{-1}$ at harvest to $3 \mu \mathrm{L} \cdot \mathrm{L}^{-1}$ after 5 weeks of storage, and then increased steadily to 22 $\mu \mathrm{L} \cdot \mathrm{L}^{-1}$ after 25 weeks of storage (Table 3). In 1995, internal $\mathrm{C}_{2} \mathrm{H}_{4}$ in AVG-treated fruit in the commercial room changed little during the first 3 months of storage but increased slowly thereafter (Fig. 2), reaching $7 \mu \mathrm{L} \cdot \mathrm{L}^{-1}$ at the end of storage. Ambient $\mathrm{C}_{2} \mathrm{H}_{4}$ around the fruit packages in the commercial storage room in 1995 ranged from
5 weeks in both the control and AVG-treated fruit. In 1995, $\alpha$ farnesene in AVG-treated fruit started to accumulate after 1 month of storage in the commercial room, and then increased rapidly to the level of control fruit at 3 months of storage (Table 4). Formation of $\alpha$-farnesene (Table 4) in ethephon-treated fruit paralleled internal $\mathrm{C}_{2} \mathrm{H}_{4}$ synthesis (Fig. 2), increasing early in storage and decreasing late in storage. Overall, $\alpha$-farnesene accumulation was similar in ethephon-treated, AVG-treated, and control fruit during cold storage in the commercial room, but was much lower in AVG-treated fruit in the low- $\mathrm{C}_{2} \mathrm{H}_{4}$ room.

Compared with the controls, ethephon treatment reduced CT281 accumulation (Table 4). AVG treatment reduced CT281 formation when fruit were stored in the low- $\mathrm{C}_{2} \mathrm{H}_{4}$ room, but not in the commercial room.

EFFECTS OF ETHEPHON AND AVG TREATMENTS ON SCALD DEVELOPMENT. Preharvest AVG treatment and low- $\mathrm{C}_{2} \mathrm{H}_{4}$ storage completely prevented scald development in 'Delicious' apples in both years (Table 5). In the commercial storage room, AVG-treated fruit developed 12\% scald in 1993 and 92\% scald in 1995 for similar periods of storage, levels similar to those of the control fruit (13\%

Table 2. Effects of AVG and ethephon preharvest treatments on fruit maturation of 'Delicious' apples in 1993 and $1995 .{ }^{\mathrm{z}}$

\begin{tabular}{|c|c|c|c|c|c|}
\hline \multirow[b]{2}{*}{ Treatment } & \multicolumn{2}{|c|}{ Internal ethylene } & \multirow{2}{*}{$\begin{array}{l}\text { Starch } \\
\text { score }^{y}\end{array}$} & \multirow{2}{*}{$\begin{array}{c}\text { Green area } \\
(\%)\end{array}$} & \multirow{2}{*}{$\begin{array}{c}\text { Firmness } \\
(\mathrm{N})\end{array}$} \\
\hline & $\left(\mu \mathrm{L} \cdot \mathrm{L}^{-1}\right)$ & $\left(\%>1 \mu \mathrm{L} \cdot \mathrm{L}^{-1}\right)$ & & & \\
\hline & & & 1993 & & \\
\hline Control & $11.6 \mathrm{a}^{\mathrm{x}}$ & $44 \mathrm{a}$ & $2.2 \mathrm{a}$ & --- & $79.2 \mathrm{a}$ \\
\hline \multirow[t]{2}{*}{ AVG } & $0.3 \mathrm{~b}$ & $0 \mathrm{~b}$ & $2.2 \mathrm{a}$ & --- & $79.2 \mathrm{a}$ \\
\hline & & & 1995 & & \\
\hline Control & $1.1 \mathrm{~b}$ & 37 & $2.1 \mathrm{~b}$ & $12 \mathrm{~b}$ & $81.0 \mathrm{~b}$ \\
\hline AVG & $0.0 \mathrm{c}$ & 0 & $1.7 \mathrm{c}$ & $19 \mathrm{a}$ & $90.3 \mathrm{a}$ \\
\hline Ethephon & $31.3 \mathrm{a}$ & 100 & $3.2 \mathrm{a}$ & $6 \mathrm{c}$ & $77.4 \mathrm{~b}$ \\
\hline
\end{tabular}

${ }^{\mathrm{z}}$ In 1993, trees were sprayed with AVG at $200 \mathrm{mg} \cdot \mathrm{L}^{-1}$ on 9 Sept. and harvested 5 Oct. In 1995, trees were sprayed with AVG at $220 \mathrm{mg} \cdot \mathrm{L}^{-1}$ on 12 Sept., with ethephon at $200 \mathrm{mg} \cdot \mathrm{L}^{-1}$ on 19 Sept., and harvested $28 \mathrm{Sept}$.

${ }^{\mathrm{y}} 1$ to $3=$ immature; 4 to $6=$ mature; 7 to $9=$ overmature.

${ }^{x}$ Mean separation within columns for a specific year by Duncan's multiple range test $(P \leq 0.05)$. 


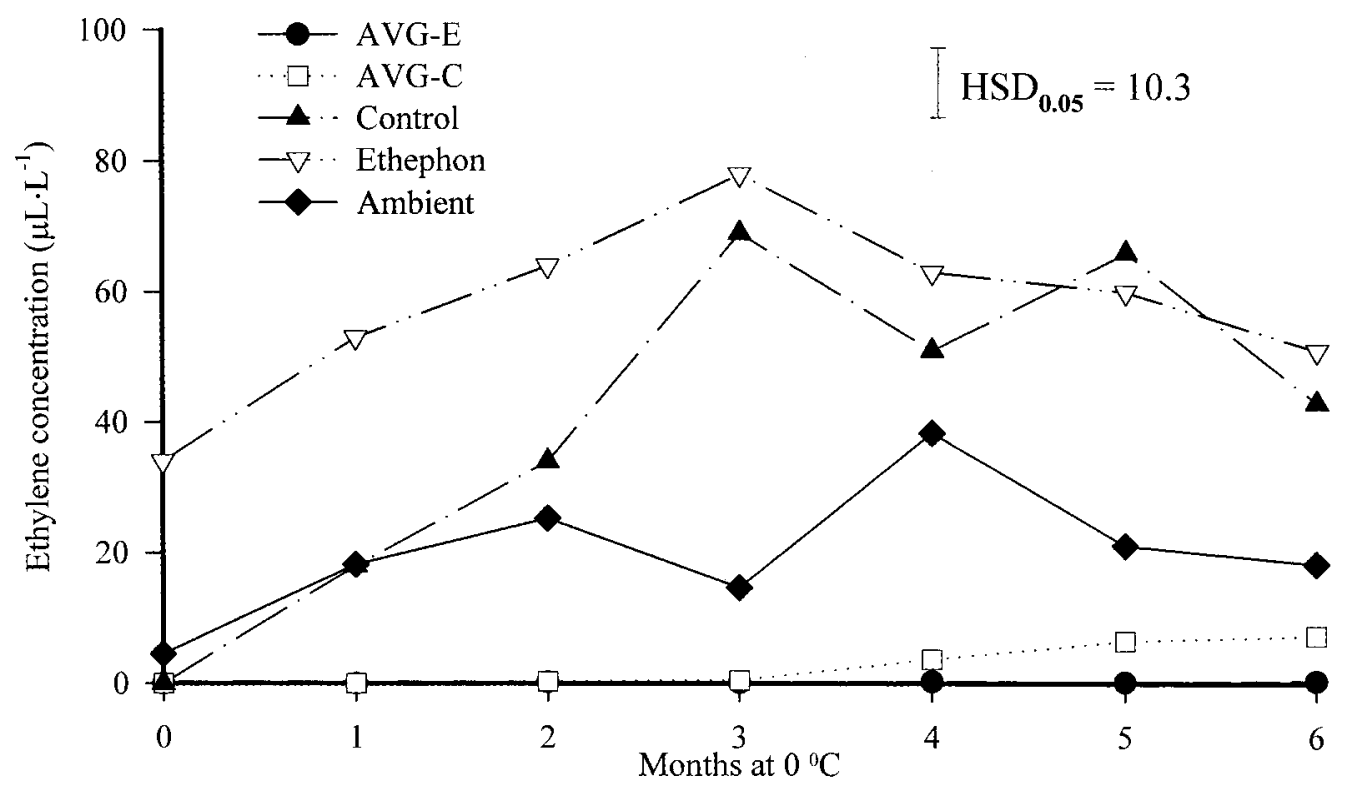

and $87 \%$, respectively). There was no difference in scald score between AVG and control treatments in a commercial storage in 1993, but the scald score of AVGtreated fruit in 1995 was higher than that of control fruit (2.6 vs. 2.2) after 25 weeks of storage (Table 5). Compared with control or AVG-treated fruit in the commercial room, ethephon treatment reduced scald by about $50 \%$.

EFFECTS OF ETHEPHON AND AVG TREATMENTS ON PHENOLIC CONTENTS IN THE CUTICLE. Ethephon treatment increased but AVG treatment decreased free and bound phenolics in cuticle compared with the controls (Fig. 3A and B). During cold storage, free phenolics in the cuticle increased

Fig. 2. Effects of AVG and ethephon treatments or storage conditions on internal ethylene concentrations in 'Delicious' apples in 1995. The interaction between treatments and storage conditions was significant. AVG-E and AVG-C represent AVG-treated fruit stored in a low-ethylene room or a commercial room, respectively. Ambient represents ethylene in air around the fruit packages in the commercial room. Control and ethephon-treated fruit were stored in the in ethephon and control fruit in early storage, but not in AVG-treated fruit (Fig. 3A), regardless of the storage conditions. Bound phenolics in fruit cuticle remained unchanged in all fruit during storage (Fig. 3B). commercial room. HSD = honestly significant difference.

Table 3. Effects of AVG on changes of internal ethylene and $\alpha$-farnesene concentrations in 'Delicious' apples at different storage conditions in $1993 .{ }^{\mathrm{z}}$

\begin{tabular}{|c|c|c|c|c|c|c|}
\hline \multirow{2}{*}{$\begin{array}{l}\text { Weeks } \\
\text { at } 0^{\circ} \mathrm{C}\end{array}$} & \multicolumn{3}{|c|}{ Ethylene $\left(\mu \mathrm{L} \cdot \mathrm{L}^{-1}\right)$} & \multicolumn{3}{|c|}{$\alpha$-Farnesene $\left(\mathrm{nmol} \cdot \mathrm{cm}^{-2}\right)$} \\
\hline & Control & AVG-C $C^{y}$ & AVG-E & Control & AVG-C & AVG-E \\
\hline 0 & 12 & 0.2 & 0.2 & 0 & 0 & 0 \\
\hline 10 & 69 & 5 & 0.7 & 215 & 191 & 20 \\
\hline 15 & 61 & 10 & 1.7 & 236 & 233 & 48 \\
\hline 25 & 85 & 22 & 8.0 & 232 & 236 & 51 \\
\hline
\end{tabular}

${ }^{\bar{z}}$ Fruit were treated with AVG at $200 \mathrm{mg} \cdot \mathrm{L}^{-1}$ on 9 Sept. and harvested 5 Oct. The interaction between treatments and storage times was significant. ${ }^{\mathrm{y}} \mathrm{AVG}-\mathrm{C}=$ fruit were stored in a commercial storage room. AVG-E = fruit were stored in a low-ethylene room.

Ns, ${ }^{*}, * * * * * * * * * * N$ Nonsignificant or significant at $P \leq 0.05,0.01,0.001$, or 0.0001 , respectively.

Table 4. Effects of AVG and ethephon preharvest treatments on changes of $\alpha$-farnesene and CT281 in 'Delicious' apples during storage at different conditions in $1995 .^{\mathrm{z}}$

\begin{tabular}{|c|c|c|c|c|c|c|c|c|}
\hline \multirow{2}{*}{$\begin{array}{l}\text { Months } \\
\text { at } 0{ }^{\circ} \mathrm{C}\end{array}$} & \multicolumn{4}{|c|}{$\alpha$-Farnesene $\left(\mathrm{nmol} \cdot \mathrm{cm}^{-2}\right)$} & \multicolumn{4}{|c|}{ CT281 $\left(\mathrm{nmol} \cdot \mathrm{cm}^{-2}\right)$} \\
\hline & Control & AVG-C ${ }^{y}$ & AVG-E & Ethephon & Control & AVG-C & AVG-E & Ethephon \\
\hline$\overline{0}$ & 0 & 0 & 0 & 24 & 0 & 0 & 0 & 0.4 \\
\hline 1 & 43 & 11 & 0 & 171 & 0.5 & 0 & 0 & 0.8 \\
\hline 2 & 87 & 42 & 0 & 165 & 2.4 & 0.8 & 0 & 1.1 \\
\hline 3 & 162 & 149 & 0.1 & 196 & 3.5 & 2.9 & 0 & 1.6 \\
\hline 4 & 186 & 146 & 0.3 & 193 & 5.7 & 4.1 & 0.1 & 1.6 \\
\hline 5 & 171 & 173 & 1.3 & 147 & 6.8 & 5.4 & 0.1 & 2.5 \\
\hline 6 & 138 & 141 & 8.1 & 96 & 8.2 & 7.3 & 0.3 & 3.4 \\
\hline \multicolumn{9}{|l|}{ Regression } \\
\hline Linear & $* * * *$ & $* * * *$ & $* * *$ & $* *$ & $* * * *$ & $* * * *$ & NS & $* * * *$ \\
\hline Quadratic & $* * *$ & $* * *$ & NS & $* * * *$ & NS & NS & NS & NS \\
\hline
\end{tabular}

$\overline{{ }^{2}}$ Trees were treated with AVG at $220 \mathrm{mg} \cdot \mathrm{L}^{-1}$ on 12 Sept. or with ethephon at $200 \mathrm{mg} \cdot \mathrm{L}^{-1}$ on 19 Sept. 1995 . Fruit were harvested $28 \mathrm{Sept}$ and stored at $0^{\circ} \mathrm{C}$ for 6 months. Control, ethephon-treated, and half of the AVG-treated fruit were stored in a commercial room, while the other half of the AVGtreated fruit were stored in a low- $\mathrm{C}_{2} \mathrm{H}_{4}$ room (ambient $\mathrm{C}_{2} \mathrm{H}_{4}$ was below $0.5 \mathrm{~mL} \cdot \mathrm{L}^{-1}$ after 6 months of storage). The interactions between treatments and storage were significant.

${ }^{\mathrm{y}} \mathrm{AVG}-\mathrm{C}=$ fruit stored in commercial room; AVG-E = fruit stored in a low-ethylene room.

Ns, ${ }^{* *}, * * *, * * * * * N$ Nonsignificant or significant at $P \leq 0.01,0.001$, or 0.0001 , respectively. 
Table 5. Effects of AVG and ethephon preharvest treatments and different storage conditions on scald development of 'Delicious' apples in 1993 and $1995 .^{\mathrm{z}}$

\begin{tabular}{|c|c|c|c|c|c|c|}
\hline \multirow[b]{3}{*}{ Treatment } & \multirow{2}{*}{\multicolumn{2}{|c|}{$\frac{1993}{\text { Scald after } 25 \text { weeks }}$}} & \multicolumn{4}{|c|}{1995} \\
\hline & & & \multicolumn{2}{|c|}{ Scald after 20 weeks } & \multicolumn{2}{|c|}{ Scald after 25 weeks } \\
\hline & $\%$ & Score $^{\mathrm{y}}$ & $\%$ & Score & $\%$ & Score \\
\hline Control & $13 \mathrm{a}^{\mathrm{x}}$ & $1.0 \mathrm{a}$ & $85 \mathrm{a}$ & $2.3 \mathrm{~b}$ & $87 \mathrm{a}$ & $2.2 \mathrm{~b}$ \\
\hline AVG-C ${ }^{\mathrm{w}}$ & $12 \mathrm{a}$ & $1.0 \mathrm{a}$ & $90 \mathrm{a}$ & $2.6 \mathrm{a}$ & $92 \mathrm{a}$ & $2.6 \mathrm{a}$ \\
\hline AVG-E & $0 \mathrm{~b}$ & $0 \mathrm{~b}$ & $0 \mathrm{c}$ & $0 \mathrm{~d}$ & $0 \mathrm{c}$ & $0 \mathrm{~d}$ \\
\hline Ethephon & & & $40 \mathrm{~b}$ & $1.8 \mathrm{c}$ & $45 \mathrm{~b}$ & $1.8 \mathrm{c}$ \\
\hline
\end{tabular}

${ }^{\bar{Z}}$ In 1993, fruit were treated with AVG at $200 \mathrm{mg} \cdot \mathrm{L}^{-1}$ on 9 Sept. and harvested 5 Oct. In 1995 , fruit were treated with AVG at $220 \mathrm{mg} \cdot \mathrm{L}^{-1}$ on 12 Sept., with ethephon at $200 \mathrm{mg} \cdot \mathrm{L}^{-1}$ on 19 Sept., and harvested 28 Sept. Scald was evaluated after cold storage and $7 \mathrm{~d}$ at $20{ }^{\circ} \mathrm{C}$.

y Score: $1=1 \%$ to $10 \%, 2=11 \%$ to $33 \%, 3=34 \%$ to $66 \%$, and $4=67 \%$ to $100 \%$ of surface area affected.

'Mean separation within columns by Duncan's multiple range test $(P \leq 0.05)$.

${ }^{\mathrm{w}} \mathrm{AVG}-\mathrm{C}=\mathrm{AVG}$-treated fruit stored in commercial room. AVG-E = AVG-treated fruit stored in low-ethylene room, where ambient ethylene concentration was below detectable limits during the whole storage period in 1993 and 1995.

\section{Discussion}

Results herein provide direct evidence that $\mathrm{C}_{2} \mathrm{H}_{4}$ regulated $\alpha$ farnesene accumulation in apples; $\alpha$-farnesene did not accumulate if exogenous and endogenous $\mathrm{C}_{2} \mathrm{H}_{4}$ levels were very low and it did accumulate when exogenous or endogenous $\mathrm{C}_{2} \mathrm{H}_{4}$ levels rose (Tables 3 and 4, Fig. 2). $\alpha$-Farnesene was stimulated by ethephon and inhibited by preharvest treatment of AVG. When AVG-treated fruit were stored in a low- $\mathrm{C}_{2} \mathrm{H}_{4}$ environment, both internal ethylene and $\alpha$-farnesene were maintained at very low levels (Tables 3 and 4 , Fig. 2).

Accumulation of free phenolics in fruit cuticle also corresponded to $\mathrm{C}_{2} \mathrm{H}_{4}$ levels. Free phenolics were higher in late harvested, high$\mathrm{C}_{2} \mathrm{H}_{4}$ fruit compared with early harvested, low- $\mathrm{C}_{2} \mathrm{H}_{4}$ fruit (Fig.1), and ethephon treatment increased free phenolics in fruit cuticle while AVG treatment caused a reduction (Fig. 3). Early in high$\mathrm{C}_{2} \mathrm{H}_{4}$ (commercial room) storage, free phenolics increased, especially in late-harvested fruit (Figs. 1 and 3). Thus, ethylene may play different scald-related roles during fruit ripening, as it induces $\alpha$ farnesene accumulation, yet stimulates free phenolic accumulation in fruit cuticle. While accumulation of $\alpha$-farnesene can increase fruit susceptibility to scald (Ingle and D'Souza, 1989; Whitaker et al., 1997), accumulation of free phenolics in fruit cuticle may increase resistance of fruit to scald due to their antioxidant activity against $\alpha$-farnesene (Ju and Bramlage, 1999). Du and Bramlage (1994) proposed that $\mathrm{C}_{2} \mathrm{H}_{4}$ had a dual effect on scald, promoting it through formation of $\alpha$-farnesene and suppressing it through an effect on the types of oxidation products formed. Our results provide evidence that free phenolics in fruit cuticle may be a suppressing factor. As hydrophilic compounds, they should be well positioned physically near the epidermal cells at the base of the fruit cuticle, so as to interfere with oxidation of $\alpha$-farnesene and transmission of injurious oxidation products from the cuticle to the cells under the cuticle, where scald occurs. When all of the data were pooled, the correlations between free phenolic concentration in cuticle and CT281 levels $(r=-0.83)$ or scald development $(r=-$ 0.61 ) were highly significant. Therefore, while $\alpha$-farnesene accumulation and oxidation are inducing factors, the presence of phenolics in fruit cuticle could be an inhibiting factor for scald development. The effect of ethylene on scald development may be determined by the balance between its stimulation of $\alpha$-farnesene and cuticular phenolics. For example, ethephon increased $\alpha$-farnesene accumulation in early storage (Table 4), but also increased free phenolics in fruit cuticle (Fig. 3). This was accompanied by lower CT281 accumulation and less scald development in ethephontreated fruit than in the controls (Table 5). Similar trends were found when early and late harvested fruit were compared (Table 1, Fig. 1).

Fig. 3. Effects of AVG and ethephon treatments on (A) free and (B) bound phenolics in the fruit cuticle of 'Delicious' apples at harvest and during storage at $0{ }^{\circ} \mathrm{C}$ in 1995 . Fruit were treated with AVG at $220 \mathrm{mg} \cdot \mathrm{L}^{-1}$ on 12 Sept. or ethephon at $200 \mathrm{mg} \cdot \mathrm{L}^{-1}$ on 19 Sept. Both AVG and ethephon-treated fruit were harvested 28 Sept. The interaction between treatments and storage conditions was significant. AVG-E and AVG-C represent AVG-treated fruit stored in a low-ethylene room or a commercial room. Control and ethephon-treated fruit were stored in the commercial room. HSD = honestly significant difference.

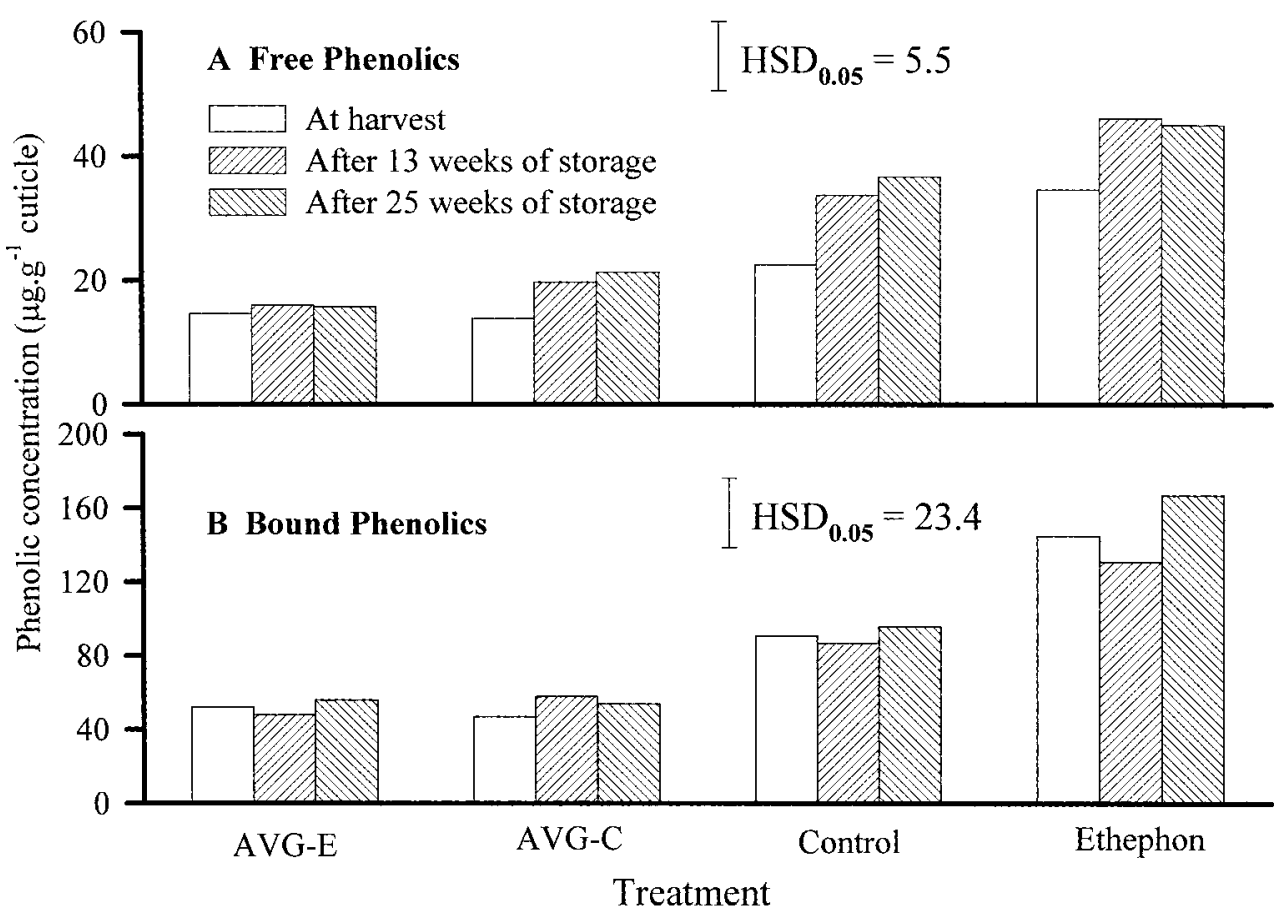


On the other hand, AVG inhibited $\alpha$-farnesene production (Tables 3 and 4), which may reduce susceptibility of fruit, but also inhibited free phenolics (Fig. 3), which may increase susceptibility of fruit to damage from oxidation of whatever $\alpha$-farnesene is present. The performance of these AVG-treated fruit was also influenced by storage condition. When they were stored in a low- $\mathrm{C}_{2} \mathrm{H}_{4}$ room, $\alpha$ farnesene was maintained at a very low level during the whole storage period (Tables 3 and 4 ) and fruit did not develop scald (Table $5)$. However, when they were stored in a commercial room where ambient $\mathrm{C}_{2} \mathrm{H}_{4}$ was high (Fig. 2), fruit accumulated a high level of $\alpha$ farnesene but not phenolics, and they developed at least as much scald as the controls (Tables 3, 4, and 5). These results illustrate that the balance between the effects of $\mathrm{C}_{2} \mathrm{H}_{4}$ on $\alpha$-farnesene and free phenolics in the fruit cuticle may play a critical role in determining scald development in apples, which supports the hypothesis of $\mathrm{Du}$ and Bramlage (1994).

Results also suggest that $\mathrm{C}_{2} \mathrm{H}_{4}$ enhancements of $\alpha$-farnesene accumulation and cuticular phenolics are altered by fruit development. Prior to harvest and early in storage, $\mathrm{C}_{2} \mathrm{H}_{4}$ stimulated both constituents of the fruit. However, later in storage (more than 13 weeks after harvest) phenolics did not increase despite high ambient $\mathrm{C}_{2} \mathrm{H}_{4}$ levels (Fig. 2 and 3). When the AVG-treated fruit were placed in a commercial room with high ambient $\mathrm{C}_{2} \mathrm{H}_{4}$, their internal $\mathrm{C}_{2} \mathrm{H}_{4}$ levels increased to physiological levels within 5 (1993) and 16 (1995) weeks, with concomitant $\alpha$-farnesene and scald increases. Accumulation of internal $\mathrm{C}_{2} \mathrm{H}_{4}$ at these developmental stages apparently did not increase cuticular phenolics (Fig. 3), leaving the fruit with less cuticular antioxidants to protect them against oxidation of $\alpha$-farnesene, and thus they developed a level of scald similar to that in controls.

Complete control of scald in this study by AVG preharvest treatment and low- $\mathrm{C}_{2} \mathrm{H}_{4}$ storage provides strong evidence that $\alpha$ farnesene accumulation in fruit cuticle is the initial factor that leads to the development of scald in apples (Huelin and Coggiola, 1968, 1970; Huelin and Murray, 1966; Whitaker et al., 1997). In addition, exogenous $\mathrm{C}_{2} \mathrm{H}_{4}$ in the commercial room induced $\alpha$-farnesene biosynthesis in AVG-treated fruit (Table 3, Fig. 2), indicating that AVG does not inhibit $\alpha$-farnesene biosynthesis directly.

\section{Literature Cited}

Anet, E.F.L.J. 1969. Auto oxidation of $\alpha$-farnesene. Austral. J. Chem. 22:24032410.

Anet, E.F.L.J. 1974. Superficial scald, a functional disorder of stored apples. XI. Apple antioxidants. J. Sci. Food Agr. 25:299-304.

Anet, E.F.L.J. and I.M. Coggiola. 1974. Superficial scald, a functional disorder of stored apples. X. Control of $\alpha$-farnesene autoxidation. J. Sci. Food Agr. 25:293298.

Autio, W.R. and W.J. Bramlage. 1982. Effects of AVG on maturation, ripening, and storage of apples. J. Amer. Soc. Hort. Sci. 107:1074-1077.

Baker, E.A., M.J. Bukovac, and G.M. Hunt. 1982. Composition of tomato fruit cuticle as related to fruit growth and development, p. 139-165. In: D.F. Cutler, K.L. Alvin, and C.E. Price (eds.). The plant cuticle. Academic Press, London.

Bangerth, F. 1978. The effect of a substituted amino acid on ethylene biosynthesis, respiration, ripening and preharvest drop of apple fruits. J. Amer. Soc. Hort. Sci. 103:401-404.

Barden, C.L. and W.J. Bramlage. 1994a. Accumulation of antioxidants in apple peel as related to postharvest factors and superficial scald susceptibility of the fruit. J. Amer. Soc. Hort. Sci. 119:264-269.

Barden, C.L. and W.J. Bramlage. 1994b. Relationships of antioxidants in apple peel to changes in $\alpha$-farnesene and conjugated trienes during storage, and to superficial scald development after storage. Postharvest Biol. Technol. 4:2333.

Bramlage, W.J., D.W. Greene, W.R. Autio, and J.M. McLaughlin. 1980. Effects of aminoethoxyvinylglycine on internal ethylene concentration and storage of apples. J. Amer. Soc. Hort. Sci. 105:847-851.

Chellew, J.P. and C.R. Little. 1995. Alternative methods of scald control in 'Granny Smith' apples. J. Hort. Sci. 70:109-115.

Curry, E.A. 1994. Preharvest applications of ethephon reduce superficial scald of 'Fuji' and 'Granny' apples in storage. J. Hort. Sci. 69:1111-1116.

Dover, C.J. 1985. Effects of ethylene removal during storage of 'Bramley's Seedling' in controlled atmosphere storage and transport of perishable commodities. Proc. 4th Natl. Controlled Atmosphere Res. Conf., Raleigh, N.C. 4:374-393.

Du, Z. and W.J. Bramlage. 1993. A modified hypothesis on the role of conjugated trienes in superficial scald development on stored apples. J. Amer. Soc. Hort. Sci. 118:807-813.

Du, Z. and W.J. Bramlage. 1994. Roles of ethylene in the development of superficial scald in 'Cortland' apples. J. Amer. Soc. Hort. Sci. 119:516-523.

Gallerani, G., G.C. Pretella, and R.A. Budini. 1990. The distribution and role of natural antioxidant substances in apple fruit affected by superficial scald. Adv. Hort. Sci. 4:144-146.

Holloway, P.J. 1992. Plant cuticles: Physiological characteristics and biosynthesis, p. 1-14. In K.E. Percy, J.N. Cape, R. Jagel, and C.J. Simpson (eds.). Air pollutants and the leaf cuticle. Springer-Verlag, Berlin.

Huelin, F.E. and I.M. Coggiola. 1968. Superficial scald, a functional disorder of stored apples. IV. Effects of variety, oiled wraps, and diphenylamine on concentration of $\alpha$-farnesene in the fruit. J. Sci. Food Agr. 19:297-301.

Huelin, F.E. and I.M. Coggiola. 1970. Superficial scald, a functional disorder of stored apples. V. Oxidation of $\alpha$-farnesene and its inhibition by diphenylamine. J. Sci. Food Agr. 21:44-48.

Huelin, F.E. and R.A. Gallop. 1951. Studies in the natural coating of apples. I. Preparation and properties of fraction. Austral. J. Sci. Res. B, 4:526-531.

Huelin, F.E. and K.E. Murray. 1966. Farnesene in the natural coating of apples. Nature (London) 210:1260-1261.

Ingle, M. and M.C. D'Souza. 1989. Physiology and control of superficial scald of apples: A review. HortScience 24:28-31.

Ju, Z.G. and W.J. Bramlage. 1999. Phenolics and lipid-soluble antioxidants in fruit cuticle of apples and their antioxidant activities in model system. Postharvest Biol. Technol. 16:107-118.

Knee, M. and S.G.S. Hatfield. 1981. Benefits of ethylene removal during apple storage. Ann. Appl. Biol. 98:157-165.

Lau, O.L. 1998. Ethylene scrubbing offers no firmness and scald benefits to 'Golden Delicious', 'Delicious' and 'Spartan' apples in low-oxygen storage. 1998, Proc. Washington. State Hort. Assn, 77-80

Lurie, S., S. Meir, and R. Ben-Arie. 1989. Preharvest ethephon sprays reduce superficial scald of 'Granny Smith' apples. HortScience 24:104-106.

Meigh, D.F. and A.A.E. Filmer. 1969. Natural skin coating of the apple and its influence on scald in storage. III. $\alpha$-Farnesene. J. Sci. Food Agr. 18:307-313.

Meir, S. and W.J. Bramlage. 1988. Antioxidant activity in 'Cortland' apple peel and susceptibility to superficial scald after storage. J. Amer. Soc. Hort. Sci. 113:412-418.

Murray, K.E., F.E. Huelin, and J.B. Davenport. 1964. Occurrence of $\alpha$-farnesene in the natural coating of apples. Nature (London) 204:80.

Priest, K.L. and E.C. Lougheed. 1988. Evaluating maturity of 'McIntosh' and 'Red Delicious' apples. Min. Agr. Food, Ontario, Canada. p. 88-117.

SAS Institute Inc. 1985. SAS user's guide: Statistics, version 5 (ed.). SAS Inst., Cary, N.C.

Shorter, A.J., K.J. Scott, G. Ward, and D.J. Best. 1992. Effect of ethylene absorption on the storage of 'Granny Smith' apples held in polyethylene bags. Postharvest Biol. Technol. 1:189-194.

Singleton, V.L. and J.A. Rossi. 1965. Colorimetry of total phenolics with phosphomolybdic-phosphotungstic acid reagents. Amer. J. Enol. Viticult. 16:144-158.

Watkins, C.B., C.L. Barden, and W.J. Bramlage. 1993. Relationships among $\alpha-$ farnesene, conjugated trienes and ethylene production with superficial scald development of apples. Acta Hort. 343:155-160.

Wee, S. and R.M. Beaudry. 1997. Scald-related volatiles in the epicuticular wax of apple fruit. HortScience 32:535 (abstr.).

Whitaker, B.D., T. Solomos, and D. Harrison. 1997. Quantification of $\alpha-$ farnesene and its conjugated trienol oxidation products from apple peel by $\mathrm{C} 18$ HPLC with UV detection. J. Agr. Food Chem. 45:760-765. 